\title{
System językowy a problemy jego opisu - o uogólnianiu na przykładzie ostatni, kolejny
}

Słow a kluc ze: metatekst; metapredykat; odniesienie; następstwo

Ke y w or d s: metatext; metapredicate; reference; sequence

„....który więc z tych okrętów jest prawdziwy: ten, który pozostaje pod dachem w rękach architektów, czy ten, który znajduje się na morzu? Z całą pewnością tylko okręt na morzu zdoła powiedzieć nam, czym naprawdę jest okręt i czym - dodajmy - jest obiekt dany nam do zbadania właśnie jako okręt." (Saussure 2004: 267).

Język jest faktem społecznym i jako taki zależy od społeczności, która się nim posługuje; mimo to nawet ta społeczność nie jest w stanie przewidzieć, w jakim kierunku „okręt popłynie”. Relacja między językiem a zbiorowością ludzką stanowi wyzwanie dla badacza, ponieważ język nie jest po prostu «strukturą», ale strukturą, która d zi ała. Co więcej, ów okręt jest też zdolny do reorganizacji w trakcie rejsu. Badania językoznawcze mają na celu odkrycie mechanizmów działania języka - nie mogą poprzestać jedynie na wyliczeniu elementów, ponieważ dopiero ich relacje tworzą system. Wykrywanie zależności między znakami w konkretnych wypowiedzeniach prowadzi do poznawania (i opisu) systemu. Wykorzystując metaforę F. de Saus- 
sure'a, można powiedzieć, że tylko po tym, jak okręt ,płynie” na pełnym morzu, możemy dochodzić do tego, czym jest okręt. W poszukiwaniu drogi badawczej badacz koncentruje się na dwóch ważnych w języku relacjach analogii i różnicy.

Podobieństwa i różnice między znakami językowymi stanowią podstawy kryteriów podziałów jednostek języka. Klasyfikacja opiera się na banalnym założeniu, że jednostka jest podobna (pod jakimś względem) do innych jednostek z tej samej klasy, a różna od jednostek innych klas (pod odpowiednim względem). Niebanalnym jest jednak pytanie, które $\mathrm{z}$ tych podobieństw i różnic są kluczowe w charakterystyce jednostki/klasy? Które z nich należy uznać za ważniejsze, w związku z czym powinny być kryterium wyższego rzędu? W systemie językowym każdy element ma swoje miejsce w układzie relacji. Do których jednostek językowych odnosi się interesujący nas element?

Badania nad jednostkami języka, którym przysługuje status ,meta”-jednostek poziomu nieprzedmiotowego, zaowocowały nie tylko opisem licznych jednostek (zob. np. Danielewiczowa 2007, 2009, Grochowski 2000, 2003), ale także nową koncepcją opisu języka (zob. Wajszczuk 2005). Analizowany i weryfikowany jest status jednostek „meta” i ich łączliwość. Charakterystyka homonimicznych jednostek z poziomu przedmiotowego i poziomu ,meta” ujawnia różnice między nimi i pozwala na precyzowanie kryteriów ich klasyfikacji. Istnieje w polszczyźnie grupa słów, które wykazują następującą właściwość: poza zewnętrznym podobieństwem łączy je także podobne (to samo?') znaczenie. Wydaje się, że pewne ciągi mogą funkcjonować i na poziomie przedmiotowym, i na poziomie meta, zachowując to samo znaczenie.

W tym artykule interesować mnie będą jednostki wyróżnione w poniższych przykładach (1-3). Ściślej, interesuje mnie ich od n i e s i e n i e:

(1) a) Ujawnia się to zwykle w następnym pokoleniu.

b) Temat ten będzie omawiany w następnym punkcie.

(2) a) Omar zdobywat kolejne wioski i miasta.

b) Wymieniano kolejne punkty konieczne do uzyskania uznania.

(3) a) Mieliśmy miejsca w ostatnim wagonie.

b) Teza ta zostaje jednak w ostatnim zdaniu ostabiona.

1 Stwierdzenie identyczności znaczenia każdorazowo wymaga analizy. 
Rozróżniając właściwie przysłówek i właściwie partykułę, J. Wajszczuk stwierdza, że „słowa różnią się nie tyle znaczeniem, co zakresem użycia, sferą zastosowania" (Wajszczuk 2005: 68). Charakterystyka semantyczna takich jednostek powinna wobec tego raczej koncentrować się na wspólnym znaczeniu i różnych ,sferach stosowania” tych jednostek/ciągów. Takie podejście z kolei uniemożliwia ich klarowną klasyfikację, ponieważ ich łączliwość i zakres występowania jest różny.

Wydaje się, że wyróżnionym w punktach (1)-(3) jednostkom nie przysługuje ten sam status: ciągi w wypowiedzeniach (1a), (2a) i (3a) mają charakter przedmiotowy, podczas gdy te wskazane w wypowiedzeniach (1b), (2b) i (3b) są użyte metatekstowo. Mówiąc inaczej, jednostki z wypowiedzeń a) odnoszą się do świata, a konteksty b) są odniesieniem do mówienia i tekstu. W każdej parze wypowiedzeń wyodrębnione ciągi reprezentują to samo znaczenie. Rozróżnienie na jednostkę przedmiotową i metatekstową jest jednak tylko pozorne. Celem jest analiza jednostek i ich właściwości, a nie kontekstu - to nie analizowane jednostki odnoszą się do świata i do tekstu, ale całe wypowiedzenia. W artykule stoję na stanowisku, że w wypowiedzeniach a) i b) (1)-(3) mamy każdorazowo do czynienia z dwoma użyciami tej samej jednostki (por. inne podejście w: Grzegorczykowa 1994), tym samym kwestia odnoszenia się i tzw. metatekstowości wymaga pewnego komentarza.

Jednostki z wypowiedzeń (1)-(3) semantycznie oparte są na relacji następstwa, zarówno w odniesieniu do zjawisk pozajęzykowych (kontekst a), jak i w odniesieniu do tekstu (kontekst b) (zob. też Grochowski 2003). Relacja następstwa zostaje zachowana w obu wypowiedzeniach. Różnica między nimi sprowadza się nie do znaczenia wyodrębnionych ciągów, ale do tematu wypowiedzeń, w których one występują: w wypowiedzeniach a) obiekt, o którym mowa, należy do świata fizycznego; w wypowiedzeniach b) obiektem, o którym się mówi, jest sam tekst. Ważniejszym pytaniem zatem wydaje mi się to, jak wybrane przymiotniki mogą opisywać rzeczy różnych kategorii, przy założeniu, że opisują je w ten sam sposób.

Weźmy przykładowe wypowiedzenia:

(4) Ostatni stanat w kolejce Osiński.

(5) Ostatni raz bytem w Polsce dwadzieścia lat temu.

(6) Przez ostatni tydzień pogoda była paskudna. 
(7) Wszystko można było ogladać na dużym ekranie usytuowanym na ostatnim piętrze kawiarni.

(8) W obszernych listach pan Jan sktadat relacje Edwardowi Chmielarczykowi o tym wszystkim, co działo się w najbliższym otoczeniu Olgi, o jej zdrowiu, stanie nerwów, wizytach znajomych, finansach. Ten ostatni temat wyraźnie dominowat nad pozostałymi.

(9) Dodany punkt rozpatrzymy jako ostatni $w$ dniu dzisiejszym.

Nie widzę uzasadnienia dla tego, by w wypowiedzeniach (4)-(7) i (8)-(9) wyróżniać dwa znaczenia słowa ostatni. Różnica odniesienia jest właściwa wypowiedzeniu, a nie przymiotnikowi ostatni. Istotą słowa ostatni jest uporządkowanie opisywanych obiektów - natura tych obiektów ma tutaj drugorzędne znaczenie. Mechanizm odnoszenia do miejsca w przyjętym porządku jest taki sam. Użycie słowa ostatni zawsze implikuje wielość obiektów tego samego rodzaju: ludzi (wypowiedzenie (4)), zdarzeń (5), tych samych jednostek czasu (6) czy tematów (8). Trudno zatem byłoby opisywać tę jednostkę raz jako przedmiotową, innym razem jako metatekstowa.

Inną jednostkę reprezentuje ciąg ostatni w poniższych wypowiedzeniach:

(10) Byłbym ostatnim idiota, gdybym się nie domyślit, co tak naprawdę powiedziała.

(11) Przy nim Steven wydawat się ostatnim egoista.

(12) Czuję sie jak ostatni drań.

Słowo ostatni w wypowiedzeniach (10)-(12) charakteryzuje się wyraźnym ograniczeniem łączliwości w stosunku do kontekstów (4)-(9). Jego dystrybucja jest ograniczona do rzeczowników wyrażających negatywną ocenę osób: ostatni drań, ostatni łotr, ostatni oszust; jego znaczenie jednak również nawiązuje do pojęcia szeregu: nadawca ustala subiektywną skalę nie dla konkretnych obiektów, ale dla stopni 'bycia draniem/egoista/idiotą'. Słowo ostatni w kontekstach (10)-(12) ma status metapredykatywny. Czym zatem jest ostatni we wcześniejszych (4)-(9) użyciach? Aby ustalić status tego wyrażenia, próbujemy odnieść ten leksem do znanych nam zbiorów jednostek: opisywana jednostka może wystąpić w kontekstach nietypowych dla ,zwykłych" przymiotników - w przeciwieństwie do nich nie przypisuje obiektowi żadnego atrybutu, trzeba ją jednakże odróżnić również od ostatni z wy- 
powiedzeń (10-12). Wystąić może w wypowiedzeniach przedmiotowych i metatekstowych.

Przymiotnik ostatni z wypowiedzeń (4-9) jest reprezentowany także w poniższych wypowiedzeniach:

(13) Jesteś ostatniq osoba, jakq spodziewatam się tu zobaczyć!

(14) Byt on ostatniq osobq, która tego dnia widziała Ewę O.

W wypowiedzeniu (13) ostatni również wyznacza miejsce w określonym układzie, choć jest ono inne niż wypowiedzenie (14). Wypowiedzenie (13) wyraża zaskoczenie nadawcy, podczas gdy (14) „obiektywny” fakt. Nie ma jednak podstaw, by uznać ostatni w (13) za słowo o innym znaczeniu niż w (14): chodzi raczej o użycie wtórne tego słowa, jego przeniesienie na wyrażenie stanu emocjonalnego mówiącego. Użycie słowa ostatni w wypowiedzeniu (13) także przywołuje pojęcie 'szeregu', tyle że porządkowane obiekty mają charakter mentalny (mówiący przywołuje w myśli wiele osób) w przeciwieństwie do obiektów przywoływanych w kontekstach (4-9).

Porównajmy wypowiedzenia z leksemem kolejny, który także wyznacza miejsce obiektu w określonym układzie:

(15) Ten napad byt absolutnie partacki - mruknat Grabinski, siegajac po kolejne ciasteczko.

(16) Kilka minut później, za kolejnym zakrętem, zobaczyli okolony murem cmentarz, na którego środku znajdowat się nieduży kościótek.

(17) Problem ten zostanie szerzej omówiony w kolejnym podrozdziale.

(18) Kolejna grupa to osobnicy o naturach destrukcyjnych, wandale, dokonujacy widocznych zniszczeń, często kierowani pragnieniem ośmieszenia nielubianej instytucji.

Mamy tu do czynienia z sytuacją podobną do tej, jaka zachodzi w wypadku leksemu ostatni: wyraźnie widać, że konteksty (17)-(18) odnoszą się do tekstu i sytuacji mówienia w przeciwieństwie do wypowiedzeń (15)-(16), co jednak nie uprawnia do założenia o dwuznaczności kolejny. Właściwością słów ostatni i kolejny nie jest odnoszenie do tekstu ani odnoszenie do świata, ale odnoszenie do układu obiektów, które występują w odpowiedniej relacji następstwa. Różnica między leksemami ostatni i kolejny sprowadza się do 
tego, w jaki sposób wyznaczają miejsce obiektu w przywoływanym szeregu: kolejny nawiązuje do obiektu, który był wcześniej (i którego obecność jest obowiązkowa), podczas gdy ostatni informuje o tym, że po nim żaden obiekt nie następuje (por. też wyrażenie: pierwszy i ostatni raz).

Zgodnie z myślą A. Bogusławskiego istotą liczebników właściwych (tzw. głównych) jest to, że wyznaczają one „kres danego zbioru w postaci jednego określonego wyrażenia szeregu arytmetycznego” (1966: 56). Z kolei: „wyrazy pierwszy, ostatni i drugi oznaczają kolejność w stosunku do „wszystkich” lub ,jednego", a zatem nie mówią o liczbie" (Bogusławski 1966: 62). Samo użycie słów kolejny czy ostatni implikuje istnienie innych obiektów. Obiekty te są jednak wskazywane według określonego klucza: „W innych użyciach tzw. liczebniki porządkowe są wyrażeniami liczebnikowymi (...), ponieważ obok liczby zawierają inną treść. (...) tzw. liczebnik porządkowy zawiera jako część treści następstwo czasowe" (Bogusławski 1966: 62).

Ten sposób rozumowania prowadzi do kolejnego pytania: czym jest przywoływany układ/szereg? Jaki jest jego status ontologiczny? Nie jest częścią świata fizycznego, czego dowodzi chociażby dowolność obiektów, do których odnoszą się przymiotniki ostatni i kolejny - jedynym ograniczeniem semantycznym jest konieczność ujęcia tego obiektu w sposób dystrybucyjny (jako całość), np. jedno z szeregu zdarzeń, jedna z ciągu myśli, jeden człowiek w kolejce itp.

Wydaje się również, że opisywany układ/porządek nie jest bytem ściśle językowym, ale jest aktualizowany wyłącznie przez język. Dopiero użycie słów pierwszy, kolejny, ostatni aktualizuje ten układ - jego status ontologiczny jest ściśle uwarunkowany językiem. Bez słów wyrażających następstwo opisywane obiekty nie wchodzą w relację następstwa ani w świadomości nadawcy, ani w świadomości odbiorcy. Tym samym nieuprawnione jest sformułowanie, że przymiotniki kolejny, ostatni o d nos z ą s i ę do układu/ szeregu - one powołują ten układ. Nie sposób zatem mówić, że proponowany szereg jest bytem pozajęzykowym.

Ten abstrakcyjny układ jest bytem mentalnym, co oznacza, że nie można opisywać jednostek ostatni, kolejny bez uwzględnienia podmiotu dokonującego oceny rzeczywistości. To nadawca tworzy relację następstwa między obiektami i dlatego ma ona charakter względny, ponieważ jest ściśle powiązana z perspektywą mówiącego. Żaden obiekt nie jest po prostu „ostatni” - 
jest ostatni dla kogoś i względem innych obiektów. Znajomość tych relacji pozwala odbiorcy trafnie wyznaczyć obiekt, o którym mowa.

Status przytoczonych tu jednostek pozostaje dla mnie kwestią otwartą, a jednocześnie skłania do analizy innych pojęć. Opisywane przymiotniki nie są „zwykłymi” przymiotnikami - nie przypisują obiektom żadnej właściwości. Nie są też jednostkami, których istotą jest funkcja anaforyczna, ponieważ używane są także w kontekstach przedmiotowych. Zawsze jednak są powiązane z podmiotem mówiącym, co nadaje im status metapredykatu, a to z kolei skłania do pytania: czym różnią się metapredykaty ostatni z wypowiedzenia np. (9) i ostatni z (10). Przymiotniki ostatni i kolejny mają też inny status niż tzw. zaimki wskazujące, wypowiedź (8) dowodzi, że słowo ten stoi na innym piętrze hierarchii niż ostatni.

Jakie właściwości - semantyczne i/lub formalne - decydują o statusie tych jednostek? Analiza pojedynczej jednostki pozwala na jej względnie pełny opis - względnie, ponieważ dopiero zestawienie jej z całym systemem daje rzeczywiście jej pełny obraz. Próba budowy spójnego opisu systemu wymaga klarownego, hierarchicznego opisu klas i relacji między jednostkami.

Potrzeba kategoryzowania jest powiązana nie tylko z badaniami językoznawczymi: jest ludzkim sposobem ujmowania wiedzy o świecie - należy uznać, że język jest również elementem świata, elementem o swoistej naturze. Uogólnienie jest zwykle kryterium podziału wyższego rzędu, cechy szczegółowe pozwalają na dokonywanie klasyfikacji wewnątrz klasy. Z formalnego (także intuicyjnego) punktu widzenia leksemy ostatni i kolejny maja typową dla przymiotnika łączliwość z rzeczownikiem, ale charakteryzują się także innymi właściwościami niż „zwykłe” przymiotniki, zob. Danielewiczowa (2007). Jeśli uznamy je za przymiotniki metapredykatywne, konieczne jest stwierdzenie, że przymiotniki metapredykatywne nie mają identycznego statusu, co oznacza, że tworzą hierarchię. Wykrycie jej pięter wymaga badań całej klasy. 


\section{Bibliografia}

BogusŁawski A., 1966, Semantyczne pojęcie liczebnika i jego morfologia w języku rosyjskim, Wrocław: Zakład Narodowy im. Ossolińskich.

Danielewiczowa M., 2007, Przymiotniki nieprzymiotniki. O pewnym niezwykłym typie wyrażeń w języku polskim, Zbornik Matice srpske za slavistiku 71-72, s. 223-236.

Danielewiczowa M., 2009, Jawnie oszczerczy, jawnie korupcyjny - między przysłówkiem a partykuła, Linguistica Copernicana 2(2), s. 57-80.

Grochowski M., 2000, Funkcja intratekstualna leksemów a ich cechy gramatyczne. Analiza wyrażenia wszelki, Poradnik Językowy 5, s. 1-8.

Grochowski M., 2003, O znaczeniach przymiotników metatekstowych następny, kolejny, w: M. Gębka-Wolak, I. Kaproń-Charzyńska, M. Urban (red.), Studia z gramatyki i leksykologii języka polskiego, Toruń: Wydawnictwo UMK, s. 197-205.

Grzegorczyкowa R., 1994, Polskie przymiotniki jako sygnały aktualizacji temporalnej wypowiedzi, w: D. Stanisheva, R. Nicolova (red.), Gramatika i semantika na slavjanskite ezici v komunikativen aspekt, Sofija: Univerzitetsko izdatelstvo Sv. Kliment Ohridski, s. 45-54.

Saussure F. DE, 2004, Szkice z językoznawstwa ogólnego, Warszawa: Wydawnictwo Akademickie Dialog.

WAsszczun J., 2005, O metatekście, Warszawa: Katedra Lingwistyki Formalnej UW.

\section{The Language System and the Problems with Its Description - on Generalization with Regard to ostatni, kolejny (summary)}

The text is devoted to the problem of criteria selection in the process of classification of language units. The problem is particularly evident in the case of lexemes, which do not comply with the general characteristics of the class. The problem was illustrated based on two Polish lexemes ostatni (the last, recent) and kolejny (next), which might be used both at the objective and the metatextual level. The use of such words updates a set/series which orders the entities that are being referred to and it is closely related to the perspective of the speaker who executes this ordering. 